\title{
Effects of sediment burial disturbance on seedling survival and growth of Suaeda salsa in the tidal wetland of the Yellow River estuary
}

\author{
Zhigao Sun • Xiaojie Mou • Guanghui Lin • \\ Lingling Wang $\cdot$ Hongli Song $\cdot$ Huanhuan Jiang
}

Received: 1 June 2010 / Accepted: 16 August 2010 /Published online: 2 September 2010

C The Author(s) 2010. This article is published with open access at Springerlink.com

\begin{abstract}
A greenhouse experiment was conducted to determine the effects of sediment burial on survival, growth and dry mass allocation of seedlings of Suaeda salsa (L.) Pall. (Chenopodiaceae), an important pioneer species of tidal wetland near the Yellow River estuary. From April to June 2009, seeds were buried at $0.5 \mathrm{~cm}$
\end{abstract}

Responsible Editor: Jeffrey Walck.

Z. Sun $(\bowtie) \cdot X$. Mou $(\bowtie)$

Key Laboratory of Coastal Environment Processes,

Yantai Institute of Coastal Zone Research,

Chinese Academy of Sciences,

Yantai 264003, China

e-mail: zgsun@yic.ac.cn

e-mail: xjmou@163.com

X. Mou

Key Laboratory of Wetland Ecology and Environment, Northeast Institute of Geography and Agroecology, Chinese Academy of Sciences,

Changchun 130012, China

L. Wang $\cdot$ H. Song $\cdot$ H. Jiang

Graduate University of the Chinese Academy of Sciences, 100039 Beijing, China

\section{Z. Sun $\cdot$ G. Lin}

Key Laboratory of the Ministry of Education for Coastal and Wetland Ecosystems, Xiamen University,

Xiamen 361005, China

Z. Sun $\cdot$ G. Lin

State Key Laboratory of Marine Environmental Science,

Xiamen University,

Xiamen 361005, China depth in plastic pots filled with sediment. Two weeks after emergence, seedlings were buried to depths of 0 (H0), 33\% (H33), 67\% (H67), 100\% (H100) and 133\% (H133) of their mean height. Results showed that seedling survivorship, height, absolute height growth rate, relative height growth rate, stem diameter, number and length of branches, dry mass and relative growth rate were significantly affected by burial depth $(P<$ 0.01). Although dry mass allocations changed with increasing burial depth, allocations to root, stem and leaf were not significantly affected by burial depth $(P>$ 0.05). No seedlings died in the partial burial treatment, approximately $18.06 \pm 5.32 \%$ seedlings survived when they were completely buried, and no seedling survived when the burial depth reached $133 \%$ of the seedling height. Seedling height, absolute height growth rate, relative height growth rate, stem diameter, number and length of branch, dry mass and relative growth rate in the partial burial treatments were much higher than those of the unburied and completely buried treatments. With increasing burial depth, there was a tendency that both allocation to root and allocation to leaf increased, while allocation to stem decreased. The stem of $S$. salsa formed adventitious roots after being buried for less than 4 weeks, which was favorable for the survival and growth of seedlings, reflecting the fact that the $S$. salsa seedlings indeed exhibit a special adaptive strategy against rapid sediment burial in tidal wetland. The burial experiment also indicated that moderate burial disturbance (H33 and H67) increased seedling vigor, while strong burial disturbance (H100) 
reduced seedling vigor. The use of thin-layer sediment burial to promote the vigor of plants in degraded wetland is very feasible, and our results provide valuable practical information applicable to the restoration of degraded $S$. salsa wetland.

Keywords Suaeda salsa . Burial depth .

Accretion rate · Seedling survival · Yellow River estuary

\section{Introduction}

Tidal wetlands are complex and dynamic, and continually changing due to the action of wind, tides and waves. Plants growing on tidal wetland are exposed to a number of extreme conditions, such as high wind velocities, drastic temperature fluctuations, high potential evapotranspiration, salt spray, low levels of soil nutrients and burial in sediment (Baldwin and Maun 1983; Maun 1998). In fact, sediment burial has been recognized as a major selective force in the evolution of seed germination, seedling emergence, seedling biomass and survivorship of seedling and adult plants (Maun 1994), and the disturbance of sediment burial affects the distribution and composition of plants in tidal wetland (Maun and Lapierre 1984). In general, plant and sediment dynamics in tidal wetland are strongly interrelated (Sanchez et al. 2001). Plant types and their coverage regulate, to some extent, the sediment dynamics of tidal wetlands, determining the direction of wetland succession (Kent et al. 2001). Wetland plants undergo burial by sediment movement and accretion (Kent et al. 2001; Owen et al. 2004), and simultaneously evolve a variety of adaptations that allow survival, growth and reproduction under relatively stressful, variable conditions (Maun 1994).

Sediment accretion not only affects the morphological characteristics of plants (such as leaf area and thickness, biomass, length of leaf, tap root, stem and internode, number of leaf, internodes and tillers, seed production) (Disraeli 1984; Zhang and Maun 1990; Maun et al. 1996; Chen and Maun 1999; Thampanya et al. 2002; Zhao et al. 2007; Deng et al. 2008), but also has significant effects on their ecophysiological indices (such as photosynthesis rate, number of bundle sheath cells, chlorophyll- $a$ fluorescence, total chlorophyll content and chlorophyll $a / b$ ratio) (Yuan et al. 1993; Zhang 1996; Maun et al. 1996; Perumal and Maun 2006). The mechanisms underlying these effects are presumably due to the major changes that occur in soil nutrient status, soil temperature, soil bulk density, microorganism composition, mycorrhizal fungi and soil aeration (Maun 1998). In general, sediment may bury seeds, seedlings and adult plants to various depths, thus increasing the vulnerability of the plants (Maun and Riach 1981). However, several studies have shown that many plants are well adapted to withstand dynamic and stochastic disturbance events (Pavlovic 1993), and some species may actually require burial in sediment to maintain high vigor (van der Putten et al. 1993). Maun (1998) also found that low levels of burial tended to stimulate plant growth, but high levels of burial were inhibitory. Thus, there could be a threshold of sediment burial for each plant to maximize vigor. Below the threshold level of burial, plant growth is stimulated by sediment burial. As the level of burial increases over the threshold, the response might be a deterioration in plant growth and vigor, and ultimately failure to survive (Zhao et al. 2007). Many studies on the responses of burial to plant growth appear in the current literature, but these reports focused mainly on arid and semi-arid dune (Sykes and Wilson 1990; Maun 1996; Brown 1997; Liu et al. 2006; Yang et al. 2007; Zhao et al. 2007; He et al. 2008), coastal and lacustrine dune (Maun 1994, 1998; Maun et al. 1996; Franks and Peterson 2003), salt marsh (Deng et al. 2008) and mangrove marsh (Lee et al. 1996; Terrados et al. 1997; Thampanya et al. 2002), and corresponding studies on tidal wetlands are very scarce.

The Yellow River is well known for having the highest sand and soil content in the world. Every year, approximately $1.05 \times 10^{7}$ tons of sand and soil is carried to the estuary (Cui et al. 2009) and deposited in the delta, where the flow rate slows down resulting in vast areas of floodplain and a very specific wetland landscape (Wang et al. 2004). Sediment deposition is an important process for the formation and development of tidal wetland near the Yellow River estuary, and the deposition rate of sediment in Yellow River affects not only the formation rate of tidal wetland, but also the salinity and extent of tidal inundation for vegetation. Sediment accretion is considered the most important controlling factor affecting seed germination, seedling emergence, seedling survivorship and seedling growth, and alteration of the salinity and 
tidal regime through sedimentation can have serious consequences for habitat stability.

Suaeda salsa is the most important vegetation type in the tidal wetland of the Yellow River estuary. As a pioneer plant of tidal wetland, it is often affected by sediment deposition resulting from tidal physical disturbance, which generally depends on prevailing wind velocities. In addition, before 2002, the low flows of Yellow River had led to a significant decrease in water supply to the wetlands, and the wetlands near the estuary exhibited varying degrees of degraded status. In order to restore the degraded wetlands, the nation carried out a "Water and Sand Regulation Project" and strengthened the scientific management of Yellow River following 2002 (Cui et al. 2009). During "water and sand regulation" (from June to July each year), the Yellow River usually floods the tidal wetland near the estuary, resulting in a large amount of sediment being deposited in tidal wetland. A sediment layer around 5-6 cm thick (Sun et al., unpublished date) forms in the $S$. salsa community during "water and sand regulation", which could have significant effects on the growth of $S$. salsa. However, little is known about the effects of sediment burial on seedling survival, growth and biomass allocation of $S$. salsa in the tidal wetland of the Yellow River estuary.

This paper reports the results of a study into the effects of sediment burial depth on seedling survival, growth and dry mass allocation of $S$. salsa. It was anticipated that there would be a threshold of sediment burial that would maximize plant vigor, and that dry mass allocation would change with increasing burial depth. The primary objectives of this paper were (1) to examine the morphological growth responses of $S$. salsa plants to sediment burial caused by single one-off burial events, and (2) to determine the threshold of sediment burial required to maximize plant vigor.

\section{Materials and methods}

Study site

This study was conducted in a greenhouse in the Shandong Key Laboratory for Eco-Environmental Science of Yellow River Delta in Binzhou University. The sediment used in this experiment was sampled from the tidal wetland $\left(37^{\circ} 46^{\prime} 38.9^{\prime \prime} \mathrm{N}, 119^{\circ} 09^{\prime} 41.4^{\prime \prime} \mathrm{E}\right)$ of the Yellow River estuary (sample depth: $20 \mathrm{~cm}$; electrical conductivity: $3.12 \pm 0.61 \mu \mathrm{s} \mathrm{cm}{ }^{-1}, n=15$ ), which is located in the Nature Reserve of Yellow River Delta $\left(37^{\circ} 35^{\prime} \mathrm{N}-38^{\circ} 12^{\prime} \mathrm{N}, 118^{\circ} 33^{\prime} \mathrm{E}-11^{\circ} 20^{\prime} \mathrm{E}\right)$ in Dongying City, Shandong Province, China. The nature reserve is of typical continental monsoon climate with distinctive seasons; summer is warm and rainy while winter is cold. The annual average temperature is $12.1^{\circ} \mathrm{C}$, and the frost-free period is 196 days. The average temperatures in spring, summer, fall and winter are $10.7^{\circ} \mathrm{C}, 27.3^{\circ} \mathrm{C}, 13.1^{\circ} \mathrm{C}$ and $-5.2^{\circ} \mathrm{C}$, respectively. The annual evaporation is $1,962 \mathrm{~mm}$, the annual precipitation is $551.6 \mathrm{~mm}$, and about $70 \%$ of precipitation occurs between June and August. The soils in the study area are dominated by intrazonal tidal soil and salt soil (Tian et al. 2005). Compared with the intrazonal tide soil, the dissolubility salt content in the upper layer $(0-20 \mathrm{~cm})$ of salt soil is much higher $\left(>8 \mathrm{~g} \mathrm{~kg}^{-1}\right)$, and its grain composition is dominated by sand and silt (50$80 \%$ ). The main vegetation types include Phragmites australis, S. salsa, Triarrhena sacchariflora, Myriophyllum spicatum, Tamarix chinensis and Limoninum sinense, etc. Tidal flat is the main wetland type, and the area is $964.8 \mathrm{~km}^{2}$, accounting for $63.06 \%$ of total area of the Yellow River Delta (Cui et al. 2009). S. salsa is the most important vegetation type in the tidal wetland of Yellow River estuary. As the pioneer plant of tidal wetland, it is often affected by the sediment deposition due to tidal physical disturbance and Yellow River flooding during "water and sand regulation" every year. In general, the sedimentary rate in the S. salsa community was $90-100 \mathrm{~mm}^{-1} \mathrm{year}^{-1}$, and about 60-70 $\mathrm{mm}$ occurred at the seedling stage, which correlated well with the significant influence of this factor seen in the "water and sand regulation project" (Sun et al., unpublished data).

Experimental method

Seeds of $S$. salsa were collected in the fall of 2008 from multiple individuals in the study area. Seeds were cleaned, dried at room temperature for $2-$ 3 weeks, then stored at $8^{\circ} \mathrm{C}$ under dry, dark conditions. The experiment was carried out on 25 April 2009. Sediment was poured into plastic pots (26 cm in diameter) up to the same depth $(17 \mathrm{~cm})$ and moistened, then the seeds ( $n=15$ per pot) were 
planted and covered with sediment at a burial depth of $0.5 \mathrm{~cm}$. The drainage outlet at the bottom of the pots was covered with strips of nylon mesh to prevent the loss of sediment while allowing drainage of excess water. During the experiment, the pots were watered regularly with tap water, and every 3 days with seawater. The salinity of the sediment of each pot was monitored daily and regulated to field conditions every 4 days. The temperature in the greenhouse was maintained at $23^{\circ} \mathrm{C}$ during the day ( $16 \mathrm{~h}$ photoperiod) and $14^{\circ} \mathrm{C}$ at night.

Two weeks after seedling emergence, we chose 34 vigorous seedlings in each pot and the others were removed. The height of each seedling in every pot was measured $(5.9-6.3 \mathrm{~cm})$, and the mean height $(H$, $6 \mathrm{~cm}$ ) above the sediment surface was calculated. Five pots were selected randomly and about 15 seedlings were sampled to determine the original dry mass of different parts. Seedlings were buried in sediment to depths of 0 (H0), 33\% (H33), 67\% (H67), 100\% (H100) and $133 \%$ (H133) of their mean height. Ten replicates per treatment were used, and there were 50 pots in total. For burial, the pots were filled with sediment around seedlings up to the appointed height. Seedlings were kept vertical while being buried. In both the H100 and the H133 treatments, the individuals were buried completely except for a few seedlings in the H100 treatment in which the leaf apices were not completely covered.

The heights of seedlings above the sediment surface were measured every week. After 4 weeks of sediment burial, the experiment was terminated. All seedlings were harvested and the survivorship of seedlings was determined using the criteria that the seedling was alive if it had fresh phloem in both stem and root, and fresh tissue in the leaf blade, and dead if the tissues were rotted. The seedlings were dug out by trowel, and the roots belonging to the seedlings were washed carefully. Seedlings were then taken to the laboratory, where the stem diameter and length were measured and the number of branches counted. Finally, the seedlings were separated into root, stem and leaf, and each fraction was weighed after drying at $80^{\circ} \mathrm{C}$ for $48 \mathrm{~h}$.

\section{Calculation}

The absolute height growth rate $\left(A H G R, \mathrm{~mm}\right.$ day $\left.^{-1}\right)$ and relative height growth rate $\left(R H G R, \mathrm{~mm} \mathrm{~cm}^{-1}\right.$ day $\left.^{-1}\right)$ of seedlings was calculated by the following equations (Zhao et al. 2007):

$A H G R=\frac{H_{2}-H_{1}}{T_{2}-T_{1}} \quad R H G R=\frac{H_{2}-H_{1}}{H_{1}\left(T_{2}-T_{1}\right)}$

Where $H_{1}, H_{2}$ are seedling height just after burial and at harvest, respectively, and $T$ is time in days. Because the height just after burial in treatment $\mathrm{H} 100$ was zero, the relative height growth rate of the seedlings was not calculated.

The relative growth rate of seedling ( $R G R$, $\mathrm{mg} \mathrm{mg}{ }^{-1}$ day $^{-1}$ ) was calculated by the following equation (Walck et al. 1999):

$R G R=\frac{L n M_{2}-L n M_{1}}{T_{2}-T_{1}}$

Where $M_{2}, M_{1}$ were the dry mass of seedlings just after burial and at harvest and $T$ was time in days.

\section{Statistical analysis}

The samples were presented as means over the replications, with standard deviation (SD). The effects of sediment burial disturbance on seedling survivorship, height, absolute height growth rate, relative height growth rate, stem diameter, number and length of branch, dry mass, dry mass allocation and relative growth rate were analyzed using the analysis of variance (ANOVA) in the treatments. If ANOVA showed significant differences, multiple comparison of means was undertaken by Tukey's test with a significance level of $P=0.05$. Since no seedlings survived from the treatment (H133), the variables were not calculated for this treatment.

\section{Results}

Effects of sediment burial on seedling survivorship

In the five treatments, survivorship was significantly affected by burial depth $(F=1,783.91, d f=4, P<$ $0.001)$. No seedlings died in the unburied treatment (H0) and partially buried treatments (H33 and H67), and approximately $18.06 \pm 5.32 \%$ seedlings survived when the burial depth reached $100 \%$ (H100) of their height. No seedlings survived when the burial depth increased to $133 \%$ (H133) of seedling height (Fig. 1). 


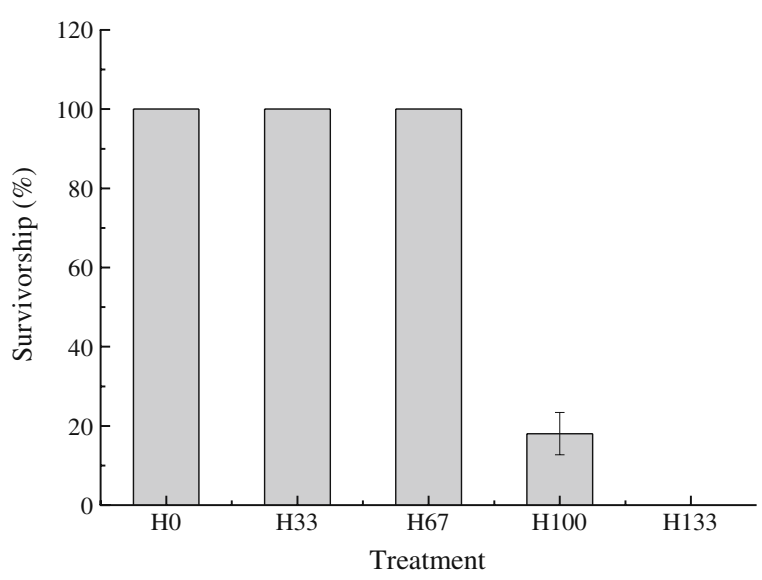

Fig. 1 Mean $( \pm \mathrm{SD})$ survivorship of seedlings buried in sediment to depths of $0(\mathrm{H} 0), 33 \%$ (H33), 67\% (H67), 100\% (H100) and $133 \%$ (H133) of their mean height $(H)$

Effects of sediment burial on seedling morphology

\section{Seedling height}

The changes in seedling height during the experiment were significantly affected by burial depth $(F=4.16$, $d f=3, P=0.031$ ), and the seedling height of the four treatments in the 1st, 2nd, 3rd and 4th weeks also had significant differences $(F=94.90, d f=3, P=0.000 ; F=$ 79.81, $d f 3, P=0.000 ; F=54.04, d f 3, P=0.000 ; F=$ 35.53, $d f=3, P=0.000$, respectively) (Fig. 2). After 1 week of sediment burial, the seedling heights of the partial burial treatments (H33 and H67) and completely buried treatment (H100) were less than those of the unburied treatment $(\mathrm{H} 0)$, and the values

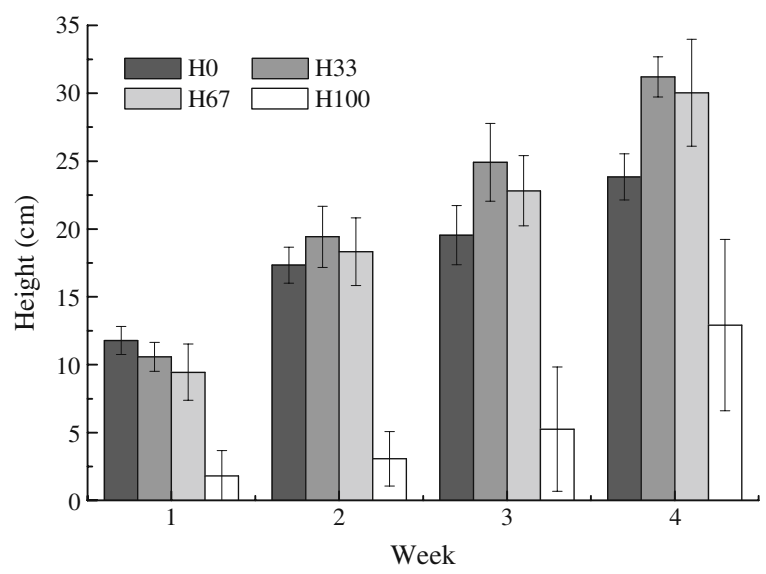

Fig. 2 Mean $( \pm \mathrm{SD})$ height over time of seedlings buried in sediment to depths of $0(\mathrm{H} 0), 33 \%$ (H33), 67\% (H67), 100\% (H100) and $133 \%$ (H133) of their mean height generally decreased with increasing burial depth. Thereafter, the seedling heights of the H33 and H67 treatments were much higher than those of the $\mathrm{H} 0$ treatment, while the values of the H100 treatment were much lower than those of the other treatments (Fig. 2). The seedling heights were usually highest in the H33 treatment, and decreased significantly when the burial depth greatly increased, indicating that while moderate burial disturbance exhibited a significant stimulation of seedling growth, the strong burial disturbance was inhibitory.

\section{Height growth rate}

After 4 weeks of sediment burial, the absolute height growth rates of seedlings were significantly affected by burial depth $(F=28.86, d f=3, P<0.001)$, and the values of the partial burial treatments were much higher than those of the unburied or completely buried treatment. Simultaneously, the relative height growth rates of seedlings were also significantly affected by burial depth $(F=235.83, \quad d f=2, P<$ 0.001 ), and the values generally increased with increasing burial depth. Both absolute growth rate and relative growth rate of the H67 treatment were much higher than those of the other treatments (Fig. 3), indicating that seedlings in the H67 treatment had the highest growth potential.

\section{Stem diameter, and number and length of seedling branches}

The stem diameters of seedlings were significantly affected by burial depth $(F=20.26, d f=3, P<0.001)$, and the values of the partial treatment were significantly higher than those of the unburied treatment $(P<0.01)$, while the values of the completely buried treatment were significantly less than those of the other treatments $(P<0.01)$ (Fig. 4). Simultaneously, the number and length of seedling branches were also significantly affected by burial depth $(F=15.31, d f=3$, $P<0.001 ; F=20.94, \quad d f=3, P<0.001$, respectively), and the values in the H33 and H67 treatments were 2.92, 4.80 times and 3.41, 5.48 times, respectively, those in the $\mathrm{H} 0$ treatment. Although the number and length of seedling branch of the H100 treatment were higher than those of the $\mathrm{H} 0$ treatment, the differences between them were not significant $(P>0.05)$. Moderate burial disturbance led to significantly 
a
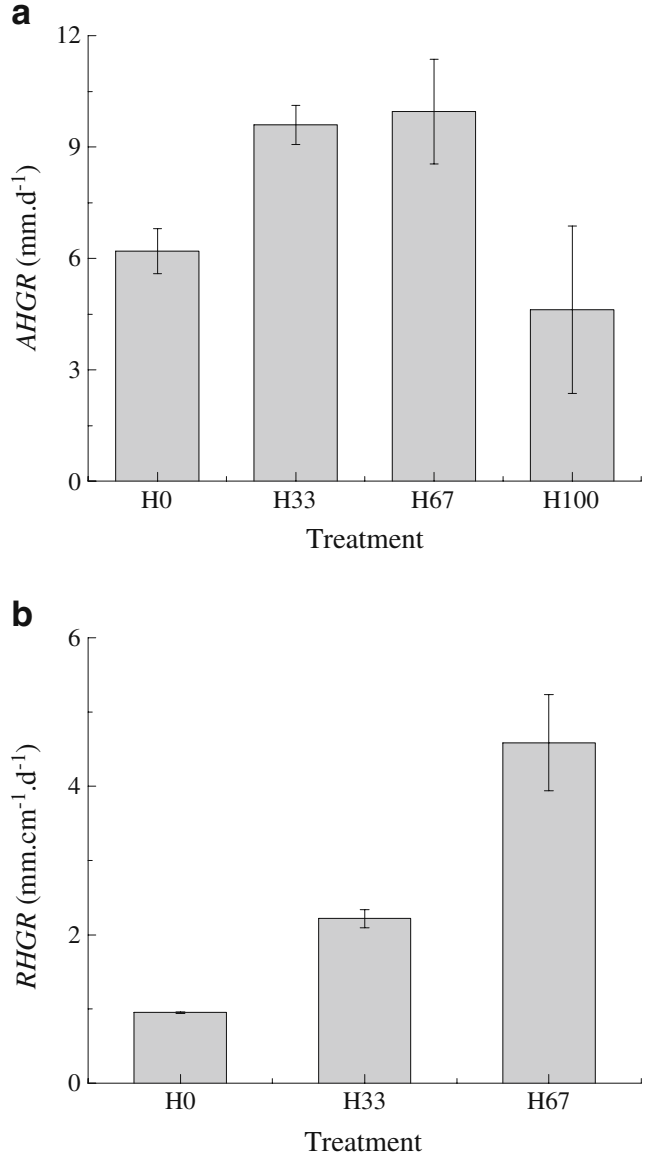

Fig. 3 Mean $( \pm \mathrm{SD})$ absolute height growth rate $(A H G R$, a) and relative height growth rate $(R H G R, \mathbf{b})$ of seedlings buried in sediment to depths of $0(\mathrm{H} 0), 33 \%(\mathrm{H} 33), 67 \%$ (H67) and $100 \%$ (H100) of their mean height

greater stimulation of the growth in stem diameter (stimulation was greatest with the $\mathrm{H} 33$ treatment), while the strong burial disturbance was inhibitory. Although the buried treatments could all stimulate growth of seedling branches, stimulation was usually greatest with the H67 treatment.

Effects of sediment burial on seedling dry mass

Dry mass and dry mass allocation

The dry mass of seedlings and their different parts (root, stem and leaf) were significantly affected by burial depth $(F=16.91, d f=3, P<0.001 ; F=23.56, d f=3, P<$ $0.001 ; F=31.58, d f=3, P<0.001 ; F=12.24, d f=3, P<$ 0.001 , respectively), with partial burial treatments leading to significantly higher values than unburied a

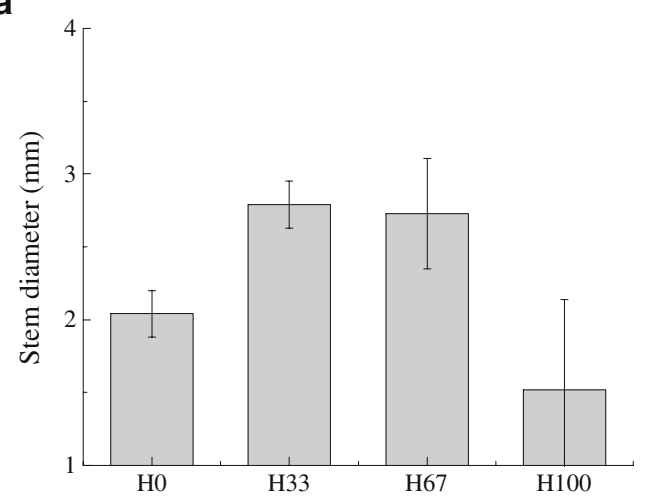

b
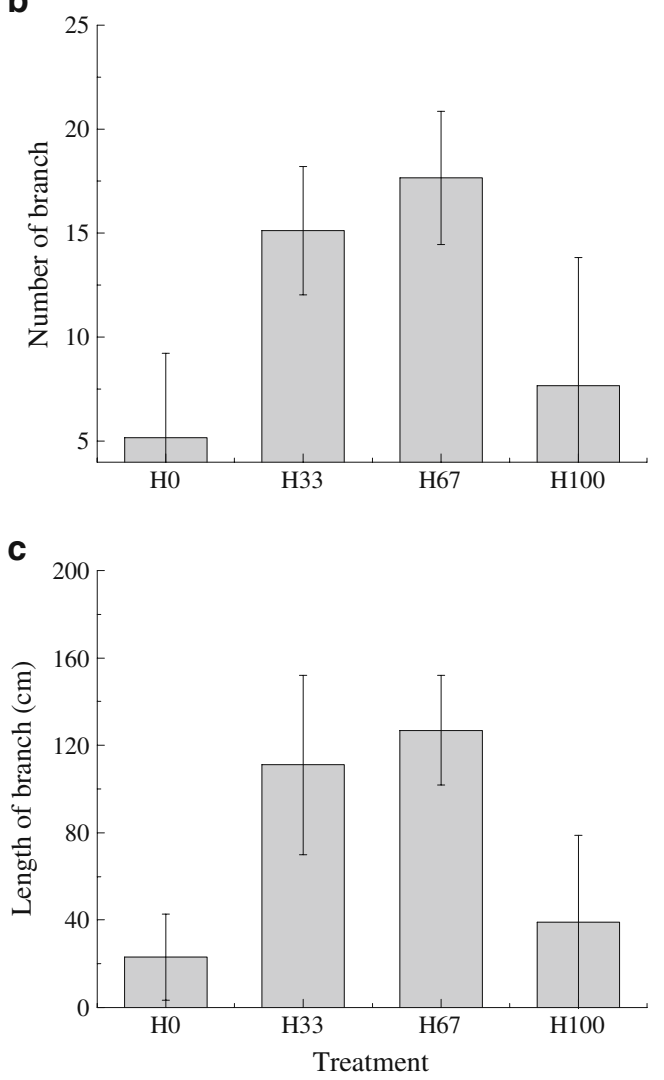

Fig. 4 Mean $( \pm \mathrm{SD})$ stem diameter (a), and number and length of branches $(\mathbf{b}, \mathbf{c})$ in seedlings buried in sediment to depths of 0 (H0), 33\% (H33), 67\% (H67), 100\% (H100) and 133\% (H133) of their mean height

or completely buried treatments $(P<0.01)$ (Fig. 5), but there were no significant differences between the H33 and H67 treatments $(P>0.05)$. Although the completely buried treatment led to lower values than the unburied treatment, the differences between them were not significant $(P>0.05)$. Moderate burial 


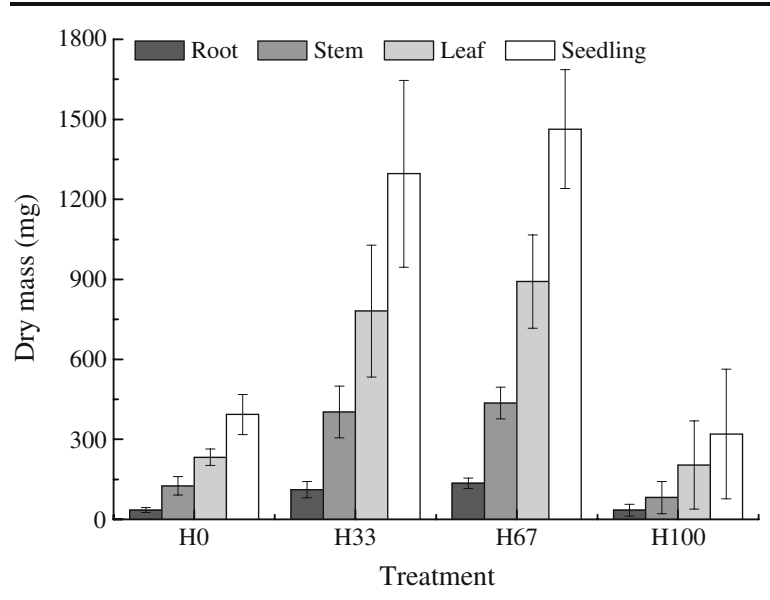

Fig. 5 Mean $( \pm \mathrm{SD})$ dry mass of seedlings buried in sediment to depths of $0(\mathrm{H} 0), 33 \%(\mathrm{H} 33), 67 \%$ (H67), 100\% (H100) and $133 \%$ (H133) of their mean height

disturbance led to significantly greater accumulation of seedling dry mass (stimulation was greatest with the H67 treatment), while strong burial disturbance was inhibitory. In contrast, the dry mass allocation to root, stem and leaf was not significantly affected by burial depth $(P>0.05)$ and, across the four treatments, there was a tendency for both allocation to root and allocation to leaf to increase with increasing burial depth, while allocation to stem decreased (Fig. 6).

\section{Relative growth rate of seedlings}

The relative growth rates of seedlings and their different parts (root, stem and leaf) were significantly affected by burial depth $(F=13.37, d f=3, P=0.002 ; F=9.89, d f=3$,

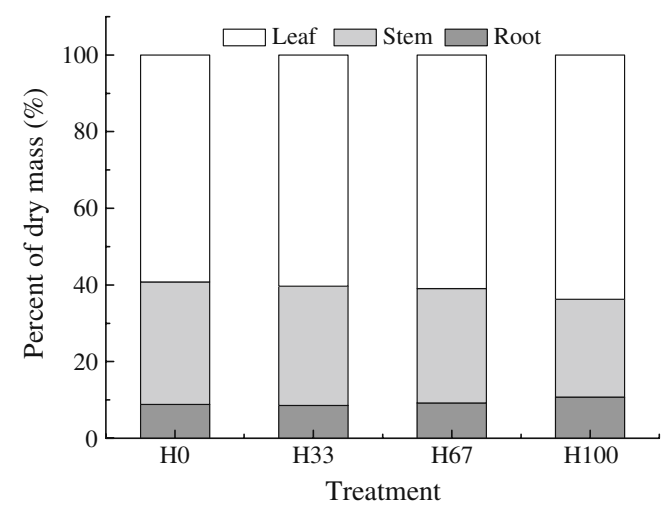

Fig. 6 Dry mass allocation of seedlings buried in sediment to depths of $0(\mathrm{H} 0), 33 \%(\mathrm{H} 33), 67 \%$ (H67), 100\% (H100) and $133 \%$ (H133) of their mean height
$P=0.003 ; F=11.71, d f=3, P=0.002 ; F=11.34, d f=3$, $P=0.002$, respectively), and the values of the partial burial treatment were significantly higher than those of the unburied treatment (Fig. 7) $(P<0.01)$. Although the relative growth rates of seedlings and their different parts in the H100 treatment were less than those in the $\mathrm{H} 0$ treatment, the differences between them were not significant $(P>0.05)$. Moderate burial disturbance exhibited significantly greater stimulation of seedling growth, while strong burial disturbance was inhibitory.

\section{Discussion}

Seedling survival after burial with sediment

This burial experiment with $S$. salsa showed that seedling survival was significantly affected by sediment burial depth. No seedlings died in the partial burial treatment, only about $18.06 \pm 5.32 \%$ seedlings survived when they were completely buried, and no seedlings survived when the burial depth reached $133 \%$ of seedling height. As the pioneer plant of tidal wetland near the Yellow River estuary, S. salsa has evolved strong adaptations to environmental stresses such as high salinity, flooding, and sediment burial. After emergence, seedlings of $S$. salsa above the sediment surface may be buried easily by sediment to various depths during establishment in late spring and early summer. Burial by tide-deposited sediment (Cheplick and Grandstaff 1997) or flood-deposited sediment during the "water and sand regulation" of

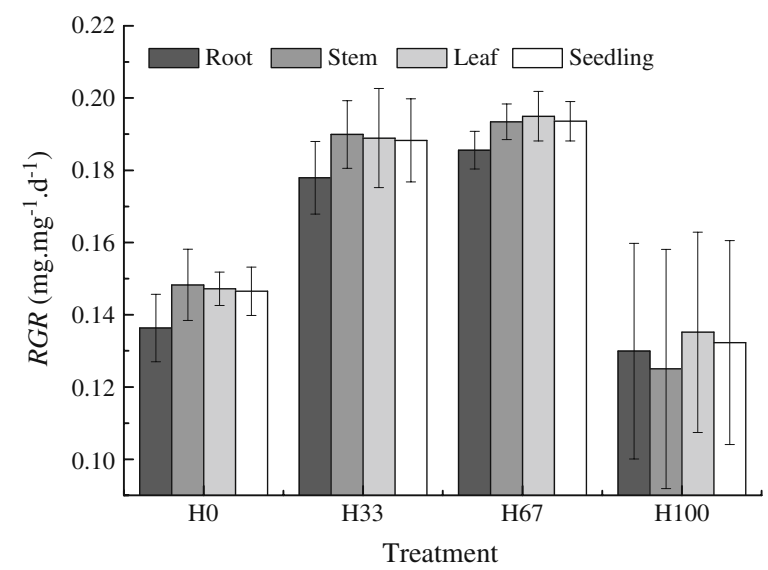

Fig. 7 Mean $( \pm \mathrm{SD})$ relative growth rate (RGR) of seedlings buried in sediment to depths of $0(\mathrm{H} 0), 33 \%$ (H33), 67\% (H67) and $100 \%$ (H100) of their mean height 
Yellow River (Cui et al. 2009) may be a critical episode for the successful establishment of these seedlings due to the strong sediment accretion in such habitats. Following burial to $100 \%$ or $133 \%$ of seedling height, normal leaf functioning was impaired and an etiolation response is observed (Sykes and Wilson 1990). The photosynthetic focus of the seedling shifted from an energy manufacturing state to an energy consuming state. Therefore, in order to survive sediment episodes, $S$. salsa must develop adaptations to overcome the suspension of photosynthetic activity, emerge from the burial deposit and then rapidly reinstate physiological activity (Perumal and Maun 2006). In general, a plant may survive if the leaves are re-exposed within a few days after a burial episode (Harris and Davy 1987) or if they grow through the sediment deposit. For emergence through a sediment deposit, the plant requires energy reserves, which are dependent on the season and stage at which a plant is buried. Davidson-Arnott and Law (1990) indicated that, in temperate latitudes where complete burial occurs in late fall, winter, or early spring, the chances of survival are good because the plant is dormant and has plenty of stored reserves. In contrast, if complete burial occurs in the late spring and summer, the chances of survival are low because the plants depends primarily on its photosynthetic area, which has been overwhelmed by sediment (Perumal 1994). Therefore, in this study, the lower seedling survivorship (18.06 $\pm 5.32 \%)$ of the completely buried treatment was also probably related to the burial time (late spring) of seedlings.

Maun (1998) described three responses of plants to sediment accretion: (1) plants have a negative response and die soon after burial (Ewing 1996); (2) plants continue to grow normally without any visible effects (Brown 1997); and (3) plant growth is stimulated (Perumal and Maun 2006). It was anticipated that there certain burial depths would increase or decrease seedling vigor. The burial experiment showed that $S$. salsa was not only capable of withstanding partial burial but also showed growth stimulation, but that when burial depth reached the whole height of the seedlings, it reduced seedling vigor. Similar results have also been reported in other systems, e.g., sediment/sand accretion (partial burial) in salt marsh or dune ecosystems promotes vigorous plant growth (Disraeli 1984; Maun and Lapierre 1984; Maun et al. 1996; Zhao et al. 2007; Deng et al. 2008). The reasons for this stimulation might be related to changes in plant growth conditions, and the primary factors might be improved soil conditions for plant growth (Disraeli 1984), mycorrhizal fungi associations (Little and Maun 1996), lowered water stress (Olson 1958) and temporary escape from harmful soil pathogens (van der Putten et al. 1993). If a plant is completely inundated by sediment, it must divert all of its stored energy to the growing organs in order to emerge above the sediment surface (Harris and Davy 1987), and the responses of plants to complete burial generally depend on their morphological and physiological characteristics (Maun 1998). In this study, the energy stored by $S$. salsa seedlings was consumed mostly by the process of emerging through sediment, and about $82 \%$ seedlings died through lack of energy. In contrast, a complete burial treatment resulted in the death of all Spartina alterniflora seedlings in the salt marsh of the Yancheng (Jiangsu Province, China) coast (Deng et al. 2008).

Time between burial and harvest of the seedlings probably affected experiment results. If the burial time in the experiment was too long, or if burial delayed shoot emergence or led to lack of oxygen, the seedlings would probably be killed. In contrast, if the burial time was short, the seedlings could withstand burial with sediment (Zhao et al. 2007). Harris and Davy (1987) indicated that seedlings at the two-leaf stage survived 1 week of burial but were killed by a 2-week treatment. In addition, sediment burial mode also probably affected experiment results. As mentioned previously, the sediment depth in the $S$. salsa community at the seedling stage was about $6-7 \mathrm{~cm}$, i.e., approximately the maximum burial depth of the experiment. In this study, the experiment was performed in a greenhouse and simulated mainly the effects of sediment burial caused by single one-off extreme burial events (such as storm tide-deposited sediment and flood-deposited sediment during the "water and sand regulation" of Yellow River) on the growth of $S$. salsa seedlings. However, the $S$. salsa community in natural habitats is most often exposed to gradual and stochastic disturbance events, and the chances of survival may be much higher. Maun et al. (1996) indicated that the burial mode had significant effects on the growth of Cirsium pitcheri, and that plants in a gradual burial treatment had higher vigor than those in a single burial treatment. One major 
difference was the length of time required to recover from burial. Single burial of plants precipitated a setback and it took a long time for plants to recover. In contrast, the plants in the gradual burial treatments recovered quickly and exhibited enhanced growth mainly because a gradually buried plant has all or most of its leaf area intact and continues to grow unabated (Lee and Ignaciuk 1985). Therefore, how gradual burial of $S$. salsa compares with a one-off burial of the same magnitude requires further study.

Seedling performance at sediment burial depth

In this experiment, the establishment of the S. salsa seedlings was influenced greatly by burial depth. Partial sediment burial not only promoted seedling growth and dry mass accumulation, and increased the number and length of branches, but also altered the dry mass allocation to different plant parts. These impacts would favor maintenance of $S$. salsa populations and encourage further growth in barren mudflats. A number of plants also use some of these morphological responses to adapt to sediment deposits. Zhang and Maun (1990) and Zhao et al. (2007) indicated that the heights of Agropyron psammophilum and Nitraria sphaerocarpa seedlings in the partial burial treatment were higher than those in the control treatment. Maun et al. (1996) found that $C$. pitcher plants grew through the sand by elongation of stem internodes, an increase in the number of nodes, elongation of petioles of leaves and the formation of new tillers. Deng et al. (2008) also indicated that burial promoted increased plant height, dry mass accumulation and the total number of clonal propagules of $S$. alterniflora.

Once emerged, successful establishment of seedlings depends primarily on their ability to rapidly attain sufficient size. Dalling and Hubbell (2002) indicated that seedling relative growth rate, rather than seedling mass, was the most important determinant of continuing recruitment success in the post-establishment phase. In this study, the relative growth rates of seedlings and their different parts in the $\mathrm{H} 33$ and H67 treatments were significantly higher than those in the $\mathrm{H} 0$ and $\mathrm{H} 100$ treatments, indicating that moderate sediment disturbance would be more favorable for the establishment of $S$. salsa seedlings. Although the seedling heights of the H67 treatment were always less than those of the $\mathrm{H} 33$ treatment during the experiment (Fig. 2), the seedling absolute and relative height growth rates were highest at the H67 treatment, indicating that seedlings in the H67 treatment had the highest growth potential. Given favorable conditions and sufficient time, seedlings with higher absolute and relative height growth rates (H67) would surpass seedlings with lower absolute and relative height growth rates (H33), despite being the same at the beginning.

In this study, a significant increase in dry mass and relative growth rate of $S$. salsa seedlings were observed in partial burial treatment as compared to controls, probably because of an increase in the growth of roots, which provide more nutrients and moderate growth conditions thus increasing the growth of shoots (Perumal and Maun 2006). Similar results were reported by Cheplick and Grandstaff (1997), who showed that growth stimulation of partially buried seedlings of Triplasis purpurea was caused primarily by an increase in root growth. Perhaps the most important factor would be an increase in root mass and the expansion of mycorrhizal fungi into the burial deposit, which would exploit the resources from the burial deposit, especially nitrogen or phosphorus, for the benefit of plants (Koske and Polson 1984). This study also showed that the stem of $S$. salsa had formed adventitious roots after being buried to different depths for less than 4 weeks (Fig. 8), and the formation of adventitious roots was favorable for seedlings to acquire more nutrients from the sediment to support shoot growth. Similar results were reported by Maun et al. (1996), who showed that most $C$. pitchers seedling stems

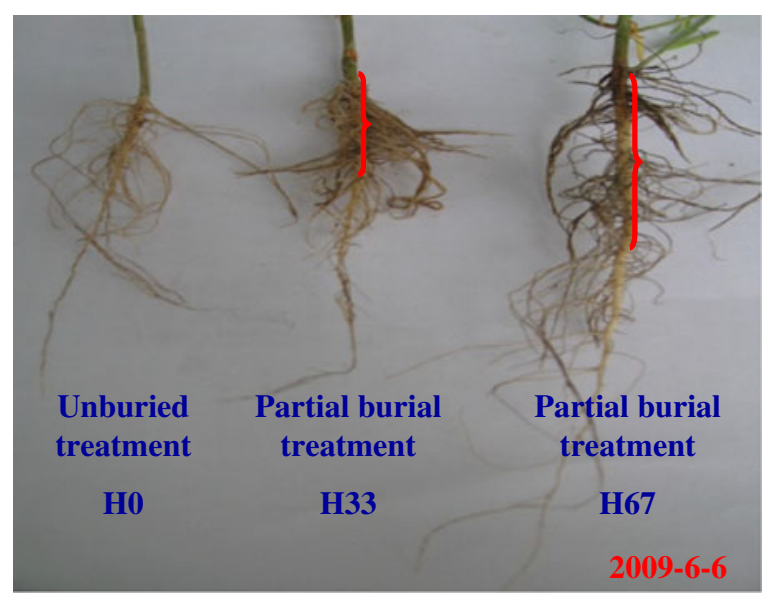

Fig. 8 Photo of seedling roots buried in sediment to depths of $0(\mathrm{H} 0), 33 \%$ (H33) and 67\% (H67) of their mean height 
formed adventitious roots after being buried for 8 weeks. The reason for the formation of adventitious roots might be related to the anaerobic conditions caused by sediment burial. Jackson (1985) indicated that anaerobic conditions favored the formation of adventitious roots and aerenchyma of salt-tolerant plants, and that these aided the survival and growth of plants after being buried. In this study, the formation of adventitious roots in the buried stem of $S$. salsa reflected the fact that $S$. salsa seedlings have evolved special adaptive strategies in response to the rapid sediment burial of tidal wetland near the Yellow River estuary.

The allocation and utilization of resources is a fundamental and vital activity of plants (Zhao et al. 2007). It was anticipated that dry mass allocation would change with increasing burial depth due to the need for vertical growth to keep up with rising sediment surfaces if the $S$. salsa seedlings were to survive. This hypothesis was tested in this experiment. With increasing burial depth, there was a tendency for both allocation to root and allocation to leaf to increase, while allocation to stem decreased. Although dry mass allocation to root, stem and leaf was not significantly affected by burial depth, changes in dry mass allocation in different burial treatments indicated that $S$. salsa could adjust its resources to tolerate different sediment stresses. Similar results were reported by $\mathrm{He}$ et al. (2008), who also showed that the dry mass allocation of Caragana microphylla seedlings was not affected by burial depth. Yang et al. (2007) indicated that, after being buried, more resources were allocated to the aboveground organs of Bromus inermis, and that the growth of aboveground organs was stimulated. In this study, the increased allocation to root and the decreased allocation to stem were related to the formation of adventitious roots in the buried stem as mentioned previously, while the increased allocation to leaf was related to the resource allocation of seedlings after being buried to different depths. In order to survive the sediment episode, $S$. salsa seedlings must allocate more resources and energy to the leaf, to favor emergence from the burial deposit and rapid reinstatement of photosynthetic activity (Perumal and Maun 2006). These results also reflect the fact that $S$. salsa seedlings exhibit important adaptive strategies to rapid sediment burial in tidal wetland near the Yellow River estuary.
Adaptation to sediment burial depth

Under regular sediment accretion, burial acts a strong selective force, and tolerance of sediment burial allows $S$. salsa to extend its range through colonization areas with sediment deposition. As analyzed previously, $S$. salsa has special adaptive strategies to deal with sediment burial in the tidal wetland of the Yellow River estuary. In our experiment, burial depths of $100 \%$ or $133 \%$ of seedling height resulted in substantial, even complete, mortality of the seedlings. From these results, it is inferred that artificial sediment binding need to be better constructed to protect seedlings from being completely buried. However, when seedlings are partially buried to a depth of $33 \%$ and $67 \%$ of seedling height, seedlings respond with increased vigor, and this response to burial could favor their survival and growth in tidal wetlands. Some plants have become so specialized that they actually require regular burial of sediment to maintain high vigor (Halun et al. 2002), and the use of thin-layer deposition of dredged materials to restore degraded wetlands has been practiced (Ford et al. 1999). In this context, the results of our study provide valuable practical information for the restoration of degraded $S$. salsa wetland.

Because this experiment was conducted in a greenhouse under controlled conditions, there are some difficulties in directly translating part of the results to the field. For instance, complicated environments and frequent disturbance in the field may decrease the positive effect of sediment accretion, or decrease the maximal burial depth that seedlings can tolerate. Moreover, the responses to burial may vary with seedlings. Therefore, further studies should investigate the behavior of different seedlings in the field, and disentangle the effects of tidal wetland elevation, nutrient status and other aspects of sediment accretion.

Acknowledgments The authors would like to acknowledge the financial support of the Innovation Program of the Chinese Academy of Sciences (No. KZCX2-YW-223), the National Nature Science Foundation of China (No. 40803023), the Talents Foundation of the Chinese Academy of Sciences (AJ0809BX-036), the Open Research Foundation of Key Laboratory of the Ministry of Education for Coastal and Wetland Ecosystems, Xiamen University (No. Cwel0903), the Advanced Visiting Scholarship of State Key Laboratory of Marine Environmental Science, Xiamen University (No. MELRS0918) and the Open Research Foundation of Key Laboratory of China Oceanic Administration for Coast Ecology and Environment (No. 200906). We thank Dr. Bo Guan for dealing with samples. 
Open Access This article is distributed under the terms of the Creative Commons Attribution Noncommercial License which permits any noncommercial use, distribution, and reproduction in any medium, provided the original author(s) and source are credited.

\section{References}

Baldwin KA, Maun MA (1983) Microenvironment of Lake Huron sand dunes. Can J Bot 61:241-255

Brown JF (1997) Effects of experimental burial on survival, growth, and resource allocation of three species of dune plants. J Ecol 85:151-158

Chen H, Maun MA (1999) Effects of sand burial depth on seed germination and seedling emergence of Cirsium pitcheri. Plant Ecol 140:53-60

Cheplick GP, Grandstaff K (1997) Effects of sand burial on purple sandgrass (Triplasis purpurea): the significance of seed heteromorphism. Plant Ecol 133:79-89

Cui BS, Yang QC, Yang ZF et al (2009) Evaluating the ecological performance of wetland restoration in the Yellow River Delta, China. Ecol Eng 35:1090-1103

Dalling JW, Hubbell SP (2002) Seed size, growth rate and gap microsite conditions as determinants of recruitment success for pioneer species. J Ecol 90:557-568

Davidson-Arnott RGD, Law MN (1990) Seasonal patterns and controls on sediment supply to coastal foredunes, Long Point, Lake Erie. In: Nordstrom K, Psuty N, Carter B (eds) Coastal dunes: form and process. Wiley, New York, pp 177-200

Deng ZF, An SQ, Zhao CJ et al (2008) Sediment burial stimulates the growth and propagule production of Spartina alterniflora Loisel. Estuar Coast Shelf S 76:818-826

Disraeli DJ (1984) The effect of sand deposits on the growth and morphology of Ammophila breviligulata. J Ecol 72:145-154

Ewing K (1996) Tolerance of four wetland plant species to flooding and sediment deposition. Environ Exp Bot 36:131-146

Ford MA, Cahoon DD, Lynch JC (1999) Restoring marsh elevation in a rapidly subsiding salt marsh by thin layer deposition of dredged material. Ecol Eng 12:189-205

Franks SJ, Peterson CJ (2003) Burial disturbance leads to facilitation among coastal dune plants. Plant Ecol 168:13-21

Halun Z, Terrados J, Borum J (2002) Experimental evaluation of the effects of siltation-derived changes in sediment conditions on the Philippine seagrass Cymodocea rotundata. J Exp Mar Biol Ecol 279:73-87

Harris D, Davy AJ (1987) Seedling growth in Elymus farctus after episodes of burial with sand. Ann Bot 61:147-157

He YH, Zhao HL, Zhao XY et al (2008) Effects of different sand burial depths on growth and biomass allocation in Caragana microphylla seedlings. Arid Land Geogr 31(5):701-706

Jackson MB (1985) Ethylene and response of plants to soil waterlogging and submergence. Annu Rev Plant Physiol 36:145-175

Kent M, Owen N, Dale P et al (2001) Studies of vegetation burial: a focus for biogeography and biogeomorphology? Prog Phys Geog 25:455-482
Koske RE, Polson WR (1984) Are VA mycorrhizae required for sand dune stabilization? Bioscience 34:420-424

Lee JA, Ignaciuk R (1985) The physiological ecology of strandline plants. Vegetatio 62:319-326

Lee SK, Tan WH, Havanond S (1996) Regeneration and colonization of mangrove on clay-filled reclaimed land in Singapore. Hydrobiologia 319:23-35

Little LR, Maun MA (1996) The Ammophila problem revisited: a role for mycorrhizal fungi. J Ecol 84:1-7

Liu Z, Yan Q, Baskin CC et al (2006) Burial of canopy-stored seeds in the annual psammophyte Agriophyllum squarrosum Moq. (Chenopodiaceae) and its ecological significance. Plant Soil 288:71-80

Maun MA (1994) Adaptation enhancing survival and establishment of seedlings on coastal dune systems. Vegetatio 111:59-70

Maun MA (1996) The effects of burial by sand on survival and growth of Calamovilfa longifolia. Ecoscience 3:93-100

Maun MA (1998) Adaptations of plants to burial in coastal sand dunes (1997) George Lawson Medal Review. Can J Bot 76:713-738

Maun MA, Lapierre J (1984) The effects of burial by sand on Ammophila breviligulata. J Ecol 72:827-839

Maun MA, Riach S (1981) Morphology of caryopses, seedlings and seedling emergence of the grass Calamovilfa longifolia from various depths in sand. Oecologia 49:137-142

Maun MA, Elberling H, D’Ulisse A (1996) The effects of burial by sand on survival and growth of Pitcher's thistle (Cirsium pitcheri) along Lake Huron. J Coast Conserv 2:3-12

Olson JS (1958) Rates of succession and soil changes on southern Lake Michigan dunes. Bot Gaz 119:125-170

Owen NW, Kent M, Dale MP (2004) Plant species and community responses to sand burial on the machair of the Outer Hebrides, Scotland. J Veg Sci 15:669-678

Pavlovic NB (1993) Disturbance dependent persistence of rare plants: anthropogenic impacts and restoration implications. In: Bowles ML, Whelan CJ (eds) Restoration of endangered species. Cambridge University Press, New York, pp 159-193

Perumal JV (1994) Sand accretion and its effects on the distribution and ecophysiology of dune plants. $\mathrm{PhD}$ Thesis. University of Western Ontario, London, ON

Perumal VJ, Maun MA (2006) Ecophysiological responses of dune species to experimental burial under field and controlled conditions. Plant Ecol 184:89-104

Sanchez JM, Sanleon DG, Izco J (2001) Primary colonization of mudflat estuaries by Spartina maritime (Curtis) Fernald in Northwest Spain: vegetation structure and sediment accretion. Aquat Bot 69:15-25

Sykes MT, Wilson JB (1990) An experimental investigation into the response of New Zealand sand dune species to different depths of burial by sand. Acta Bot Neerl 39:171-181

Terrados J, Tampahnya U, Srichai N et al (1997) The effect of increased sediment accretion on the survival and growth of Rhizophora apiculata seedings. Estuar Coast Shelf S 45:697-701

Thampanya U, Vermaat JE, Terrados J (2002) The effects of increasing sediment accretion on the seedlings of three common Thai mangrove species. Aquat Bot 74:315-325

Tian JY, Wang XF, Cai XJ, et al (2005) Protection and restoration technique of wetland ecosystem in Yellow River Delta. China Ocean University Press, 2005 
van der Putten WH, van Dijk C, Peters BAM (1993) Plantspecific soil-borne diseases contribute to succession in foredune vegetation. Nature 362:53-55

Walck JL, Baskin JM, Baskin CC (1999) Relative competitive abilities and growth characteristics of a narrowly endemic and a geographically widespread Solidago species (Asteraceae). Am J Bot 86:820-828

Wang FY, Liu RJ, Lin XG et al (2004) Arbuscular mycorrhizal status of wild plants in saline-alkaline soils of the Yellow River Delta. Mycorrhiza 14:133-137

Yang HL, Cao ZP, Dong M et al (2007) Effects of sand burying on caryopsis germination and seedling growth of Bromus inermis Leyss. Chin J Appl Ecol 18(11):2438-2443
Yuan T, Maun MA, Hopkins WG (1993) Effects of sand accretion on photosynthesis, leaf-water potential and morphology of two dune grasses. Funct Ecol 7:676-682

Zhang J (1996) Interactive effects of soil nutrients, moisture and sand burial on the development, physiology, biomass and fitness of Cakile edentula. Ann Bot 78:591598

Zhang J, Maun MA (1990) Effects of sand burial on seed germination, seedling emergence, survival, and growth of Agropyron psammophilum. Can J Bot 68:304-310

Zhao WZ, Li QY, Fang HY (2007) Effects of sand burial disturbance on seedling growth of Nitraria sphaerocarpa. Plant Soil 295:95-102 